\title{
The Utilization of Digital Platforms for Marketing in the Nigerian Entertainment and Media (E\&M) Industry: Prospects and Challenges
}

\author{
Nelson Obinna Omenugha (Corresponding author) \\ $\mathrm{PhD}$ Scholar and Teaching Assistant \\ School of Films and TV Arts, Xi'an Jiaotong-Liverpool University, China \\ E-mail: nomenugha@gmail.com or n.omenugha@xjtlu.edu.cn
}

Received: May 2, 2018 Accepted: May 28, 2018 Published: June 2, 2018

doi:10.5296/csbm.v5i1.13240 URL: http://dx.doi.org/10.5296/csbm.v5i1.13240

\begin{abstract}
The National Bureau of Statistics recently announced that the entertainment and media (E\&M) industry in Nigeria recorded growth of $1.86 \%$ to $12.81 \%$; contributing N54bn to the country's GDP. The industry's revenue is projected to reach an estimated $\$ 8.5 \mathrm{bn}$ in 2018, from $\$ 4 \mathrm{bn}$ in 2013, with internet as one of the key drivers (PwC report, 2016, p.14). This comes at a time when Nigeria's economy has shrunk by $2.24 \%$ since 2015 and receded by $0.18 \%$ from the previous quarter. Therefore, this study unpacks the possibilities and challenges of the impact of e-marketing tools on the growth of the Nigerian E\&M industry. E-marketing tools provide "a unique combination of powerful capabilities for marketers" (Parsons et al., 2015). E-marketing suitability for the E\&M industry lies in its lower capital demand, and a convenient and online means of disseminating marketing messages across a heterogeneous population at an unlimited geographical space. E-marketing is a reality in Nigeria as a study by Mathew, Ogedebe \& Ogedebe (2013, p. 549) shows that "Many Nigerians who used (sic) the internet as one form of communication or another are bombarded daily with advertisements of products and services from industries in the country." This reality has brought a shift from mechanical to electronic and from analogue to digital; ultimately impacting the marketing realms. The internet enables these electronic/digital platforms; which marketers (E\&M industry) and customers (content consumers) rely on to effectively reach and receive communication content and feedback respectively. However, this study examined the challenges that have possibly hindered the full realization of the e-marketing tools of the Nigerian E\&M industry and noted among others; poor power supply and unreliable network infrastructure in the country. There is also an increased customer expectation, security, content copyright and privacy issues as well as the challenge of
\end{abstract}




\section{Macrothink}

compliance demand in the industry as influenced by ever dynamic digital boundaries. There is a huge economic need for the Nigerian government to live up to its obligation and enhance power supply and boost network infrastructure. The Nigerian E\&M industry needs to continually integrate different digital platforms to reach targets and attract more content consumers. Both the government and industry should increasingly learn and bring a global perspective that can help the nation adapt to the constantly changing digital environment.

Keywords: Internet, New media technologies, Digital platforms, E-marketing, Nigerian Entertainment and Media (E\&M) industry, Content and Consumer, Security, Content Copyright and Privacy. 


\section{Macrothink \\ Case Studies in Business and Management \\ ISSN 2333-3324 \\ 2018, Vol. 5, No. 1}

\section{Introduction}

Nigeria is a developing economy in Africa, albeit with appreciable potentials for greatness given its large labour force and abundance in natural resources, including petroleum and natural gas, as well as arable land and water resources (Durojaiye, 2003; Akasike, 2007; Hassan, 2011). However, as things stand today, the nation is struggling to feed her large population, create jobs for its overwhelming workforce and ensure evenly distributed general socio-economic empowerment amongst the citizenry (Durojaiye, 2003). Consequently, there remains the need for strategies and actions towards accelerated economic growth and empowerment in the country.

Amongst the avenues long recognized as crucial for securing better economic fortunes for Nigeria is the entertainment and media (E\&M) industry in the country; notably, the film industry (which is adjudged the most prolific in the world and the second biggest employer after the government) and the mobile Telecommunications industry (Omenugha, 2015). Both have recorded significant success stories in recent years (Open Society Foundations, 2012; Dare, 2011; Pyramid Research, 2010). A report by PwC's Global entertainment and media outlook 2017-2021 asserted that Nigeria produces around 2,500 films a year; a figure that makes it the second biggest production hub after India. Indeed, the entertainment and media (E\&M) industry has been described as a vital element in the nation's economy given its vibrancy and contribution to the nation's economy; including the GDP. It provides a viable platform through which a large portion of the population can launch themselves to economic success which in turn creates wealth and job opportunities for many others (Federal Ministry of Finance, 2012). Sectors dominated in entertainment and media (E\&M) industry such as film and music have emerged as leading contributors to the nation's gross domestic product (GDP) - with motion pictures contributing 1.4\% of this as at 2014 (Liston, 2014). According to the $2016 \mathrm{PwC}$ report, the industry's revenue is projected to reach an estimated $\$ 8.5 \mathrm{bn}$ in 2018 , from $\$ 4 \mathrm{bn}$ in 2013. This comes at a time when for the past three years, Nigeria's prime crude oil product price has fallen from over $\$ 100 /$ barrel to $\$ 30 /$ barrel (Nwoba, Nwonu \& Agbaeze, 2017); ultimately shrinking its economy since 2015. 
Double-digit growth expected throughout forecast period

Entertainment and media spending by segment (US\$ millions), 2011-2020

\begin{tabular}{|c|c|c|c|c|c|c|c|c|c|c|c|}
\hline \multirow{3}{*}{ Nigeria } & \multicolumn{11}{|c|}{ Total E\&M (US\$ millions) } \\
\hline & \multicolumn{5}{|c|}{ Historical data } & \multicolumn{5}{|c|}{ Forecast data } & \multirow{2}{*}{$\begin{array}{l}\text { CAGR \% } \\
2015-20\end{array}$} \\
\hline & 2011 & 2012 & 2013 & 2014 & 2015 & 2016 & 2017 & 2018 & 2019 & 2020 & \\
\hline Books & 37 & 37 & 39 & 41 & 44 & 46 & 48 & 50 & 52 & 55 & \\
\hline YOY growth (\%) & & $1.8 \%$ & $4.6 \%$ & $5.9 \%$ & $5.4 \%$ & $5.0 \%$ & $4.8 \%$ & $4.5 \%$ & $4.3 \%$ & $4.0 \%$ & $4.5 \%$ \\
\hline Business-to-business & 15 & 15 & 17 & 19 & 20 & 22 & 23 & 25 & 27 & 29 & \\
\hline YOY growth (\%) & & $3.7 \%$ & $10.5 \%$ & $12.0 \%$ & $6.5 \%$ & $6.3 \%$ & $6.6 \%$ & $7.2 \%$ & $7.8 \%$ & $8.1 \%$ & $7.2 \%$ \\
\hline Cinema & 70 & 75 & 80 & 87 & 95 & 104 & 114 & 123 & 134 & 144 & \\
\hline YOY growth (\%) & & $6.6 \%$ & $7.3 \%$ & $8.1 \%$ & $9.4 \%$ & $9.5 \%$ & $9.1 \%$ & $8.7 \%$ & $8.3 \%$ & $7.8 \%$ & $8.7 \%$ \\
\hline Internet & 506 & 826 & 1136 & 1488 & 1919 & 2275 & 2672 & 3115 & 3587 & 4089 & \\
\hline YOY growth (\%) & & $63.3 \%$ & $37.5 \%$ & $31.0 \%$ & $28.9 \%$ & $18.6 \%$ & $17.4 \%$ & $16.6 \%$ & $15.1 \%$ & $14.0 \%$ & $16.3 \%$ \\
\hline Magazines & 160 & 172 & 179 & 185 & 189 & 191 & 194 & 196 & 197 & 198 & \\
\hline YOY growth (\%) & & $7.2 \%$ & $4.5 \%$ & $3.2 \%$ & $2.0 \%$ & $1.4 \%$ & $1.1 \%$ & $1.0 \%$ & $0.8 \%$ & $0.5 \%$ & $1.0 \%$ \\
\hline Music & 40 & 42 & 42 & 44 & 47 & 51 & 57 & 66 & 75 & 86 & \\
\hline YOY growth (\%) & & $2.8 \%$ & $1.6 \%$ & $3.8 \%$ & $6.4 \%$ & $9.0 \%$ & $12.1 \%$ & $15.6 \%$ & $13.5 \%$ & $14.6 \%$ & $12.9 \%$ \\
\hline Newspapers & 168 & 166 & 166 & 166 & 166 & 167 & 169 & 172 & 174 & 174 & \\
\hline YOY growth (\%) & & $-0.9 \%$ & $0.0 \%$ & $-0.4 \%$ & $0.0 \%$ & $0.6 \%$ & $1.4 \%$ & $1.7 \%$ & $1.4 \%$ & $0.1 \%$ & $1.0 \%$ \\
\hline Out-of-home & 134 & 145 & 157 & 170 & 181 & 193 & 206 & 221 & 240 & 263 & \\
\hline YOY growth (\%) & & $8.0 \%$ & $8.9 \%$ & $7.9 \%$ & $6.3 \%$ & $6.7 \%$ & $6.7 \%$ & $7.6 \%$ & $8.6 \%$ & $9.4 \%$ & $7.8 \%$ \\
\hline Radio & 66 & 70 & 72 & 76 & 78 & 81 & 83 & 86 & 89 & 91 & \\
\hline YOY growth (\%) & & $5.0 \%$ & $4.0 \%$ & $4.5 \%$ & $3.2 \%$ & $3.3 \%$ & $3.3 \%$ & $3.2 \%$ & $3.1 \%$ & $3.0 \%$ & $3.2 \%$ \\
\hline TV and video & 788 & 829 & 903 & 976 & 1021 & 1054 & 1088 & 1128 & 1162 & 1205 & \\
\hline YOY growth (\%) & & $5.1 \%$ & $9.0 \%$ & $8.0 \%$ & $4.7 \%$ & $3.3 \%$ & $3.2 \%$ & $3.7 \%$ & $3.0 \%$ & $3.7 \%$ & $3.4 \%$ \\
\hline Video games & 45 & 54 & 64 & 76 & 88 & 101 & 116 & 134 & 147 & 150 & \\
\hline YOY growth (\%) & & $19.1 \%$ & $19.7 \%$ & $18.1 \%$ & $15.5 \%$ & $15.4 \%$ & $15.2 \%$ & $15.4 \%$ & $9.1 \%$ & $2.4 \%$ & $11.4 \%$ \\
\hline Total & 2015 & 2414 & 2841 & 3308 & 3826 & 4263 & 4746 & 5290 & 5854 & 6454 & \\
\hline YOY growth (\%) & & $19.8 \%$ & $17.7 \%$ & $16.5 \%$ & $15.7 \%$ & $11.4 \%$ & $11.3 \%$ & $11.5 \%$ & $10.7 \%$ & $10.2 \%$ & $11.0 \%$ \\
\hline
\end{tabular}

Notes: Figures for 2011-2015 have been updated to reflect the most recently available financial information.

Newspaper directory, consumer magaxine, trade magazine and online TV advertising are included in their respective segments and also in

Internet advertising, but only once in the overall total.

Professional books is counted in business-to-business and books, but only once in the overall total.

Trade magazines is counted in business-to-business and magazines, but only once in the overall total.

Sources: Entertainment and media outlook: 2016-2020 - South Africa-Nigeria-Kenya, PwC, Ovum

However, to succeed, the entertainment and media (E\&M) industry (like large scale investments), requires certain business strategies and tools which crucially include marketing. While marketing is vital for achieving and sustaining market breakthrough for commercial ventures, it is basically capital intensive - at least in its traditional form (Akasike, 2008), potentially making it a burden - at least in its budding stage. Notably, the 2016 PwC report identified internet as one of the key drivers of the successes recorded in the Nigerian entertainment and media (E\&M) industry.

Against the foregoing, an alternative, as represented by digital marketing (e-marketing), becomes worth considering. Digital marketing or e-marketing is a form of marketing that employs digital platforms, primarily computers and the internet to reach the target audience (Aker, 2008). Parsons, Zeisser and Waitman (1998, p.32) describes it thus: 
By digital marketing, we mean two activities: first, leveraging the unique capabilities of new interactive media (e.g., World Wide Web, on-line services, proprietary dial-up services) to create new forms of interactions and transactions between consumers and marketers; and second, integrating interactive media with the other elements of the $50 \%$ of these consumers will access inter-marketing mix.

Among others, the e-marketing tools include the Social media, Search Engine Optimization, E-mail marketing, Blog sites, Mobile Marketing and Pay per Click (Paid Advertising on website). These tools have radically brought changes on how business are conducted. While they are arguably not changing who we are, what we do and how we conduct our activities are definitely been changed. We now have a smarter consumers who are not so interested in becoming one-way consumer of communication content as presented by the traditional media; but rather a co-creators of the content (Failte Ireland, 2012). Through engaging in online and social media networks, consumers are finding out among others; what content to create, products to buy and services to use based on value proposition and gratification from such platform.

As an e-marketing tool, the social media is a digital platforms that allow individuals and businesses to launch and form social networks through a mutual conversation and engagement with other users. Among others, these platforms include Facebook, Twitter, LinkedIn, Instagram, and YouTube. Another e-marketing tool is the search engine optimization (SEO); which is a process used to boost website to enable it feature more and have an enhanced online presence in Google searches. There is also the e-mail marketing tool; which provides for an online engagement and exchanges with the current and potential users through e-mail services. Newsletters, bulletins and other informative contents are communicated to the users through the e-mail channel. As one of the crucial e-marketing tools, the website platform is used to promote businesses online through providing detailed information that assist users to comprehend products and services as well as guide through the patronizing journey.

Digital marketing's suitability for the entertainment and media (E\&M) industry lies in its lesser capital demand, as online and other digital platforms will disseminate marketing messages across an unlimited geographical space at very reasonable costs. Digital marketing excludes the huge cost implication of traditional mass media marketing and using interactive online platforms it can facilitate relationship marketing in an effective, convenient and very cost-saving manner (Akasike, 2008; Omenugha, 2015). In fact, the interactive features of the digital online platforms such as the social media constitute "a unique combination of powerful capabilities for marketers" (Parsons et al., 2015). However, beyond these specific advantages, the imperative of digital marketing in the contemporary world for all businesses including the entertainment and media (E\&M) industry is well captured by Wymbs (2015) when he aptly observes that the realities of the shift from mechanical to electronic and from analogue to digital; have had their inevitable impact on the realms of marketing. The scholar further notes that digital platforms are unsettling the old ways of doing things, such that today's consumers have become "digital consumers" meaning that for the marketers to effectively reach and communicate to them, they ought to become "digital marketers". 


\section{MlMacrothink}

The entertainment and media (E\&M) industry in Nigeria, arguably, now has digital marketing at their disposal. This is given the increasing accessibility of digital communication platforms in the country - chiefly the internet and mobile phones (Uche, 2010; Amaefule, 2012; Omenugha, 2015), which naturally predispose the population to digital marketing participation. That this sort of marketing is already a reality in Nigeria is evident in the observation by Mathew, Ogedebe \& Ogedebe (2013, p. 549) that "Many Nigerians who used (sic) the internet as one form of communication or another are bombarded daily with advertisements of products and services from companies around the globe."

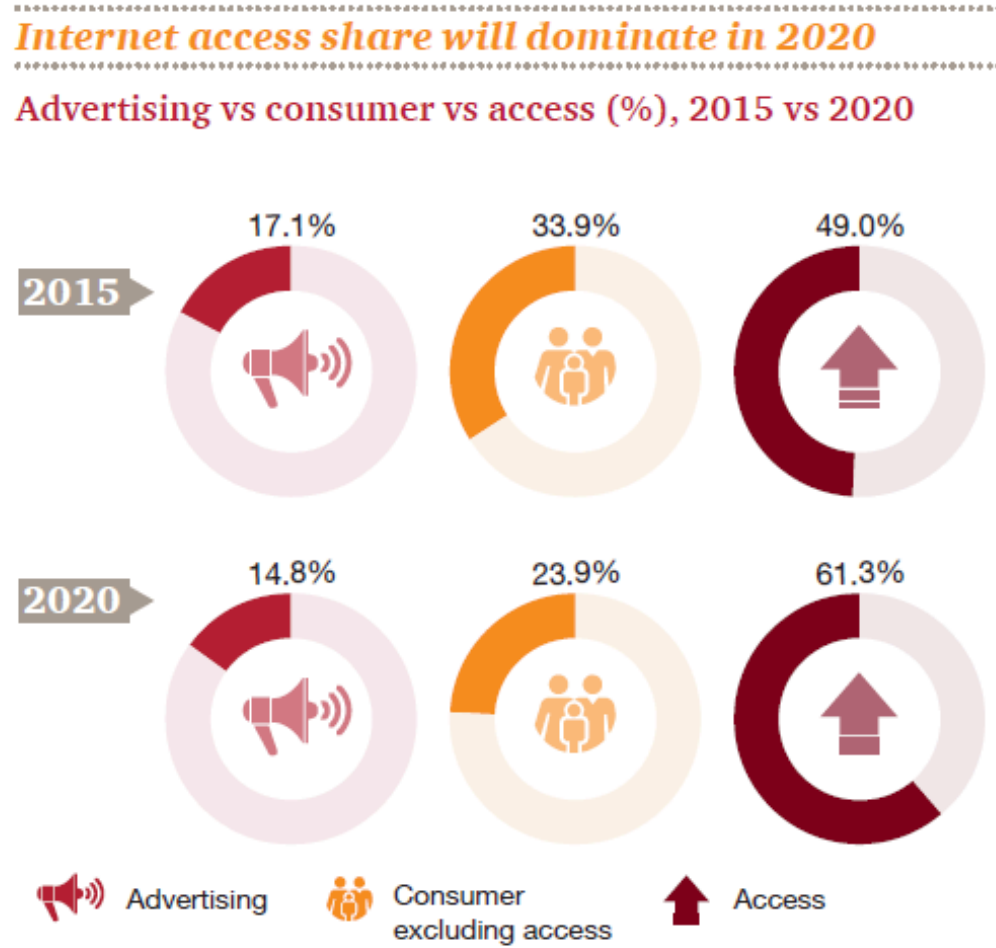

Sources: Entertainment and media outlook: 2016 - 2020 • South Africa - Nigeria - Kenya, PwC, Ovum

It is against this backdrop that this study attempts to unpack the possibilities and challenges of the impact of e-marketing tools on the growth of the Nigerian entertainment and media $(\mathrm{E} \& \mathrm{M})$ industry. As stated earlier, the entertainment and media (E\&M) industry is a cardinal contributor to the economic growth of Nigeria; with the major objective being to be productive and contribute to the nation, local consumption and export (Federal Ministry of Finance, 2012). This research is a potential catalyst for achieving this policy objective. The information generated by the study will offer insight into the potential and challenges of the impact of e-marketing tools on the industry which strives to boost its activities through digital innovations. Such insight will potentially place the policymakers and the entertainment and media (E\&M) industry themselves in a more strategic position to explore more possibilities in this direction. In other words, the study will expand the existing debate on utilization of digital platforms for marketing among the players and investors in the Nigerian entertainment 
and media $(\mathrm{E} \& \mathrm{M})$ industry as well as better guide the investors and policymakers on business decisions. Similarly, the research will enrich literature in the area of new media and social networking technologies; ICTs-assisted marketing and related subjects. It will serve to improve knowledge and potentially become a stepping stone for further inquiry.

\section{Literature}

Studies have tended to show that the application of digital platforms in marketing in Nigeria have generally produced positive results. These notably include reduced marketing expenditure (Aker, 2008; Adetayo, Sanni and Ilori, 1999); enhanced sales (Adetutu and Eze, 2008; Adetayo et al., 1999) and improved customer relations (Hassan, 2011; Omenugha, 2015). Further studies (Akasike, 2008; Inyang, Odu and Eleme, 2012; Akam, 2014) have examined the nature of uses which firms in Nigeria make of digital platforms in their marketing endeavours. Findings have generally indicated that tools like social media and mobile phones have been deployed towards developing content, reaching more targets and building relationships with existing ones. Some of the online platforms have - albeit limitedly - been applied in sales activities.

Nevertheless, literature has generally shown that digital marketing is yet to be fully optimized in Nigeria (Inyang et al., 2012; Akam, 2014; Peters, 2015). This reflects in the theoretical assumption that appears to have underpinned many of these previous studies - an assumption that since digital technologies have become available and proven efficient, every economic sector in Nigeria would, as a matter of spontaneous response, embrace them. This echoes the technological determinism theory which affirms that our way of life is determined by the technologies available at our own time (Baran \& Davis, 2001); in other words, we are without choice and freewill as far as technology is concerned. However, the gap in this conceptualization becomes obvious once we bring in the theory of the social construction of technology (or technological constructivism) which affirms that the nature of technology that thrives in a society is conditioned (determined) by the society's aspirations, worldview, beliefs - in fact its entire cultural realm (Sassen, 2002). Thus, previous empirical literature has mainly tended to view Nigeria as one of those climes caught up in the irresistible global "spell" of digital technology, hence the apparently wrong assumption that the same level of digital technology application and impact found in western societies would inevitably apply in the country. Thus, why technological determinism is clearly useful in viewing the state of digital marketing in Nigeria, social construction of technology complements it by bridging the gap between the general and the particular; between technology isolated from social realm and technology captured in its social context.

The above-mentioned presents the conceptual /theoretical gap that this paper attempts to address. Has the Nigerian entertainment and media (E\&M) industry fully optimized the new media technologies and digital platforms in a manner that it should? What are the attendant opportunities? Which challenges undermine these e-marketing efforts and strategies? How can these challenges be overcome to enable the industry utilize the digital platform at its optimal? 


\section{Macrothink \\ Case Studies in Business and Management \\ ISSN 2333-3324 \\ 2018, Vol. 5, No. 1}

\section{Prospects}

The import of the entertainment and media (E\&M) industry to the economic growth of a developing economy and an emerging market such as Nigeria cannot be over-emphasized. According to PwC's Global entertainment and media outlook 2017 -2021, the most rapid growth rates in E\&M revenues over the coming five years will be in less-developed markets and economies, where entertainment and media (E\&M) spending on a per capita basis is generally quite low - less than US\$50 yearly. Interestingly, the latest report notes that Nigeria with a $12.1 \%$ compound annual grow rate (CAGR) is strongly influenced by surging spending on mobile internet access; predicting the country would be the world's fastest-growing entertainment and media $(E \& M)$ market over the same period while the slowest-growing will be Japan, growing at a $1.7 \%$ CAGR. The local film sector alone is estimated to employ more than 1 million people; generating more than US\$7billion for the national economy as well as accounting for $1.4 \%$ of GDP. Arguably, this suggests that there are dramatic shift in business approaches and the emergence of creative ways in which the Nigerian entertainment and media (E\&M) industry compete and generate value in terms of content development, content communication (marketing) and customer engagement. Studies have linked customer quality of experience in terms of creative communication content, collaborative communication channels and customer relationship to strategic corporate differentiation and revenue growth (Mathew, Ogedebe, \& Ogedebe, 2013; Jobber \& Ellis-Chadwick, 2013; Omenugha, 2015). Simply put, the unique value proposition and revenue growth of an industry is arguably tied to the industry's capacity to develop creative content and adapt interactive communication platforms to reach, engage and satisfy their targets; ultimately achieving its marketing objectives. Omenugha (2015) notes that the objective of any marketing effort is to engage, recruit and trigger customer's patronage (action) of the particular products or services. He argued that for marketing efforts to be successful, the brand, product or service would have to be able to persuade and move targets into taking positive action on it. Consequently, for the optimal attainment of the marketing objectives in the Nigerian entertainment and media (E\&M) industry, this suggest that the players must have to combine compelling content using the new media technologies and through the digital platforms and other strategy; reach and persuade users; as well as generate great user experience that would trigger positive actions (patronage). 


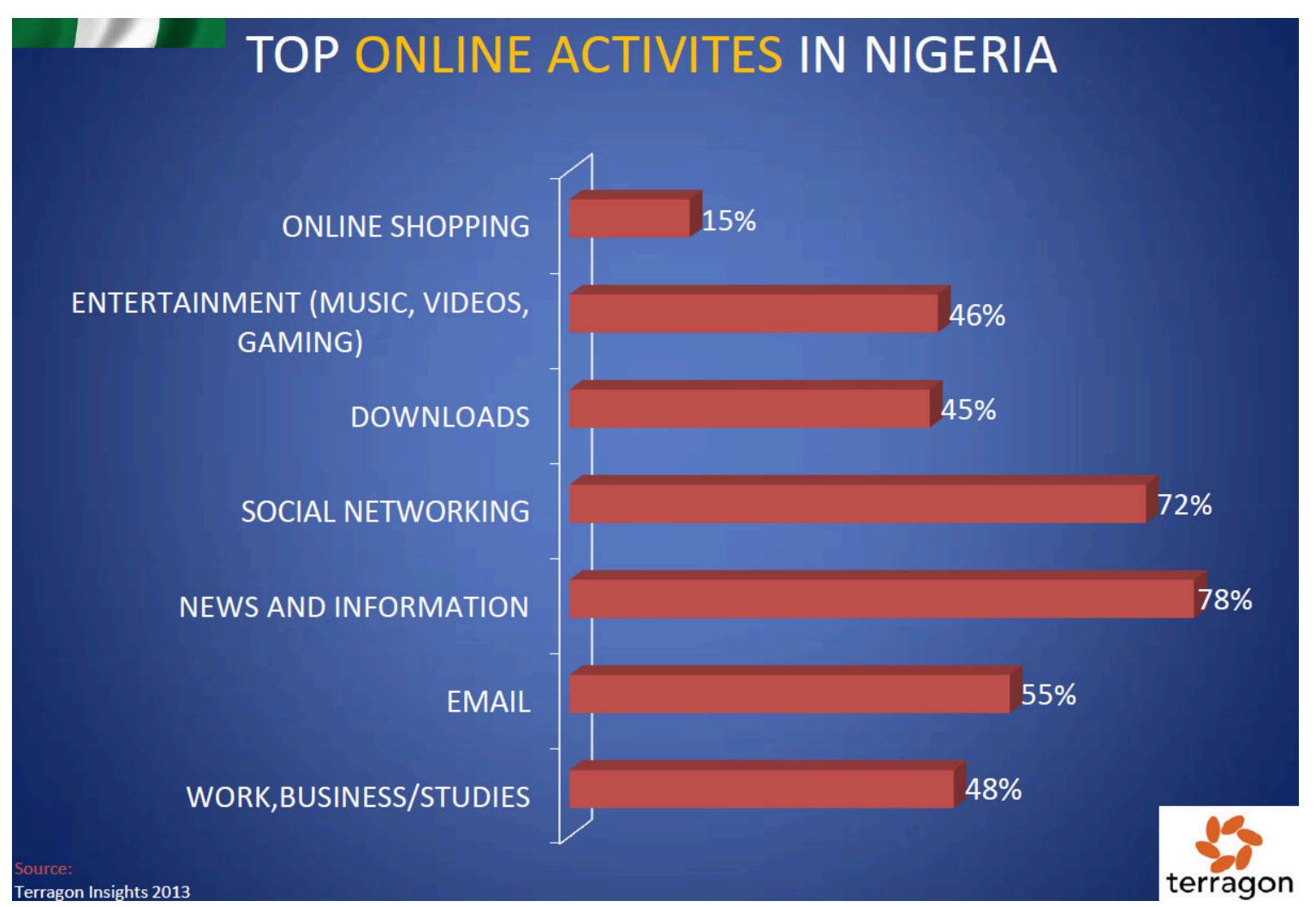

Recognizing the role of online platforms and the new technologies in marketing (e-marketing), Femi Osinubi, Technology, Information, Communications and Entertainment (TICE) Industry Leader at PwC Nigeria, notes:

A raft of changes in technology, user behaviour and business models have opened up a gap between how consumers want to experience and pay for E\&M offerings, and how companies produce and distribute them. The right user experience bridges this gap. To deliver it, companies must pursue two related strategies. First, build businesses and brands anchored by active, high-value communities of fans, united by shared passions, values, and interests. And second, capitalize on emerging technologies to delight users in new ways and provide superior user experiences.

The digital platforms and new media technologies are key catalysts that drive the Nigerian entertainment and media (E\&M) industry and present potentials for the advancement of creative and economic activities of the industry.

Other potentials include; driving Direct-to-Targets (D2T) marketing strategies. The digital platforms present the perfect chance for sectors in the entertainment and media (E\&M) industry such as film, music, broadcast and print media to go online; using the new media technologies and digital platforms to specifically identify and reach their targets with content about their services in real time.

Summarizing the potentials and opportunities presented by the digital platforms for marketing, Osere Alakhume, the Partner and TICE industry leader for PwC West Africa submits: 
The steady march of digital technology has ushered in a more direct-to-consumer environment characterized by greater choice and user control. Amid an ever greater supply of media, businesses that are fan-centric will find themselves with audiences that are more engaged, more loyal, and spend more per capita. To thrive in the experience-driven marketplace characterized by this year's Outlook, companies need to attract and harness the economic, social, and emotional power of fans.

As user experience has a common relationship with patronage and revenue, these capacities of the entertainment and media (E\&M) can harness new technologies and digital platforms to communicate their creative content; generate traffic to their content, engage their targets and capture insights into what the users want. This would potentially stimulate more users-driven content and improvement of content that would be appreciated locally and compete globally. For instance, by adapting the new media technologies such as high performing digital cameras and video gadgets, the Nigeria Nollywood has been able to improve the quality of their movie production and through social media platforms like Facebook, YouTube and other interactive platforms to bring awareness about the release of a new movie in the country. Social media provides platforms for the movie producers and characters to target direct-to-consumer (D2C). Through disseminating promotional videos of the movies via these platforms, targets are engaged and persuaded to either share, like or make comment. This provides for user control and opportunities to generate traffic to the film; ultimately to increase revenue. With the substantial inclination to new media technologies; including social media platforms by the Nigeria film and music segment of the E\&M industry, the PwC's Global entertainment and media outlook 2017-2021, predicts that over the next five years, internet video will grow at 11.6\% CAGR, and music streaming at 20.7\% CAGR.

Another potential that digital platforms present for marketing activities in entertainment and media $(E \& M)$ industry is the driving of a robust mobile advertising strategy. E-marketing activities and the deep penetration of internet in Nigeria are largely driven by increasing access to mobile phones (Terragon, 2013). The Nation's deregulation of its telecommunication; allowing for private sector participation has led to a phenomenal degree of mobile penetration (Juwah, 2011) with an attendant high internet expansion. Given the interactive, portable, user-friendly and digital nature of smart mobile phones, people increasingly rely on it to access and assess e-marketing creative contents as well as transact businesses (Adomi, 2005). The 2015 GSMA intelligence report records that Nigeria has 85 million mobile subscribers. This mobile platform has presented the platform to target, reach and engage the entertainment and media users. For example, very competitive and creative broadcast and print media establishments in Nigeria have developed Mobile Application (App) through which subscribers can stream and view news stories as well as offer feedback on news content. This strategy is one of the ways these media outfits are coping with the disruptive nature of new media technologies on the traditional media. The emergence of the digital platforms and new media technologies has impacted conventional ways news is gathered and delivered as well as in hard readership and revenue. Particularly, these digital platforms and technologies have created opportunity for different people to become media prosumer (producer and consumer); irrespective of not having any formal journalism training. 


\section{Macrothink}

Case Studies in Business and Management

ISSN 2333-3324

2018, Vol. 5, No. 1

These practitioners have access to happenings in their immediate environment and elsewhere and are also able to produce news stories and report them with their smartphones which are readily accessible to the internet. They also access and consumer what other users produce and publish online. Readership and Revenue has also shifted from hard to soft copy; seeing users reading news online as well as advertising in the digital platforms. To remain in business, media organizations (including the print and broadcast media establishment) in Nigeria are evolving strategies for dealing with the challenges of new technologies; particularly by adapting the digital platforms to inform users about new offerings, providing opportunities for immediate feedback and ultimately driving traffic to their mobile App platforms. Smart mobile phones are also overwhelmingly used by the entertainment and media (E\&M) targets to download new music and movies; including writing reviews about such music and movies. This leads to the capture of more insights into what users want, more data and more revenue. According to the PwC's Global entertainment and media outlook 2017-2021, mobile advertising in Nigeria has grown by $58.7 \%$ in the past year and will continue to grow at $18.5 \%$ compound annual growth rate (CAGR) through 2021 . However, while the studies such as those conducted by Terragon and $\mathrm{PwC}$ indicate that there are appreciable number of e-marketing and digital dealings in Nigeria; they revealed that over $84 \%$ of the population living in urban cities have access to smart mobile phones as against $58 \%$ of rural dwellers. This indicates that any analysis of e-marketing strategies in Nigeria E\&M industry would be largely focused on metropolitan areas.

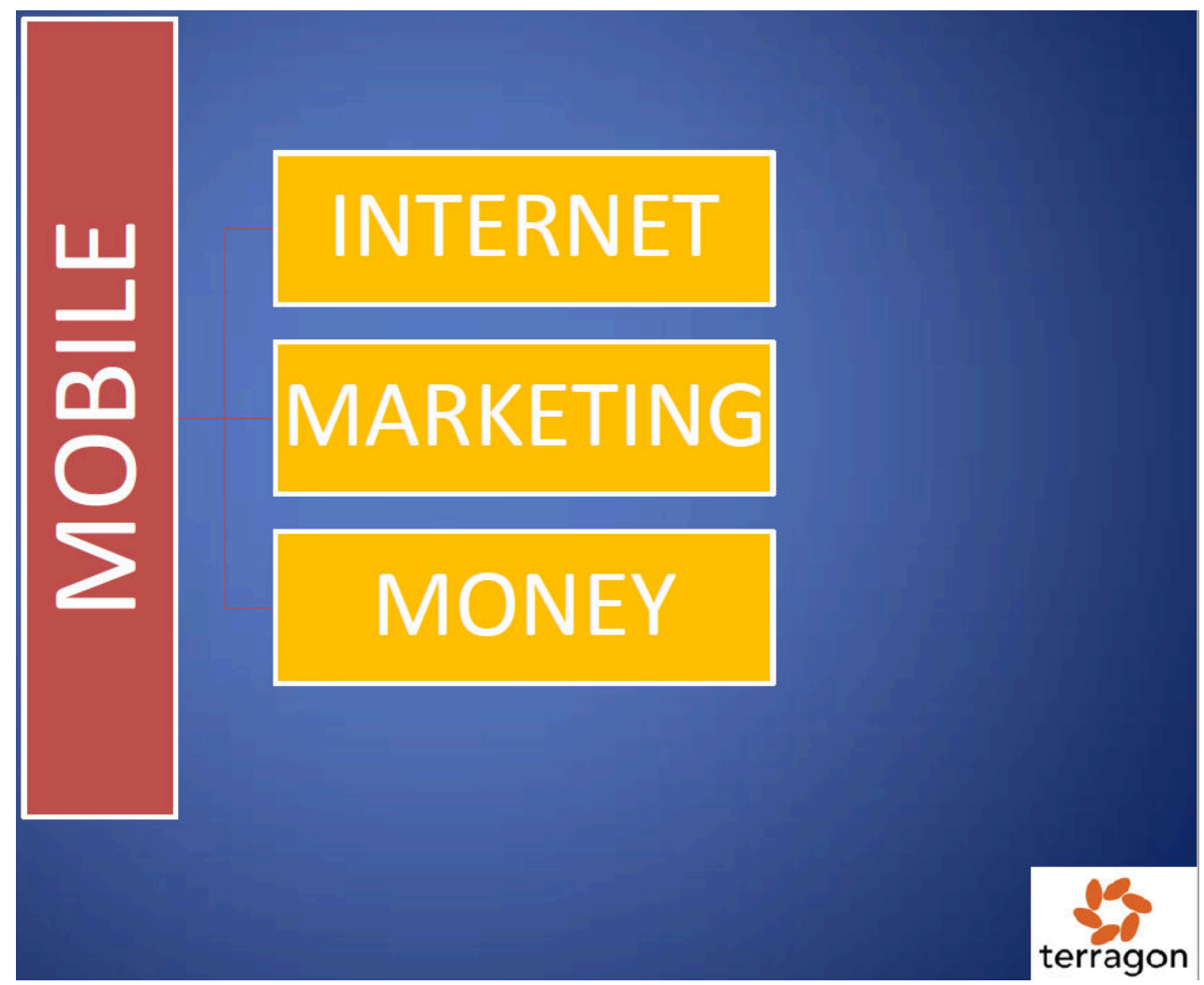

Finally, another identified potential is the emerging of a more robust and competitive platforms. 


\section{Ml Macrothink \\ Case Studies in Business and Management \\ ISSN 2333-3324 \\ 2018, Vol. 5, No. 1}

The activities of e-marketing in the entertainment and media (E\&M) industry has present potentials and opportunities for the emergence and development of other online platforms through which players increasingly rely upon to reach, recruit and retain users. By providing innovative and enhancing platforms, a robust and competitive environment is created for the users' active participation and ultimate growth of the industry. For instance, in the Nigeria Film entertainment industry, platforms like Irokotv, Netflix, and Cinema have emerged to provide alternative competitive digital platforms for digital marketing; co-creating and co-distributing values to millions of users who are fans to the platforms. Particularly, Femi Osinubi, Technology, Information, Communications and Entertainment (TICE) Industry Leader at PwC Nigeria remarked that Nigerian cinema is on a rebound; with new theaters opening and production quality increasing. He predicted that Nigerian cinema revenue would hit US\$22 million in 2021, rising at 8.6\% CAGR over the forecast period. This offers an insight that could suggest that over the period, cinema office revenue will be on the increase; ultimately attracting investment, international recognition as well as return on investment (ROI). Equally, these emerged and emerging platforms are providing the springboard for the emergence of new artists in the Nigerian music entertainment industry; who utilize these platforms to advertise and showcase their new music. This display attracts the big players and fans of the industry who either reach out to support the upcoming artist or share the music to gain more views. As a lot of music are created in Nigeria, there is the need to embark on an intensive marketing activities to reach as many persons and places; and digital marketing possesses the capacity to achieve this. According to the PwC's Global entertainment and media outlook 2017-2021, hundreds of albums are produced annually in Nigeria which cover a wide range of genres. The Nigerian music revenue is also reported to have increased by $9 \%$ in 2016 to hit US\$39 million, and is set to rise to $13.4 \%$ CAGR to US\$73 million in 2021. 


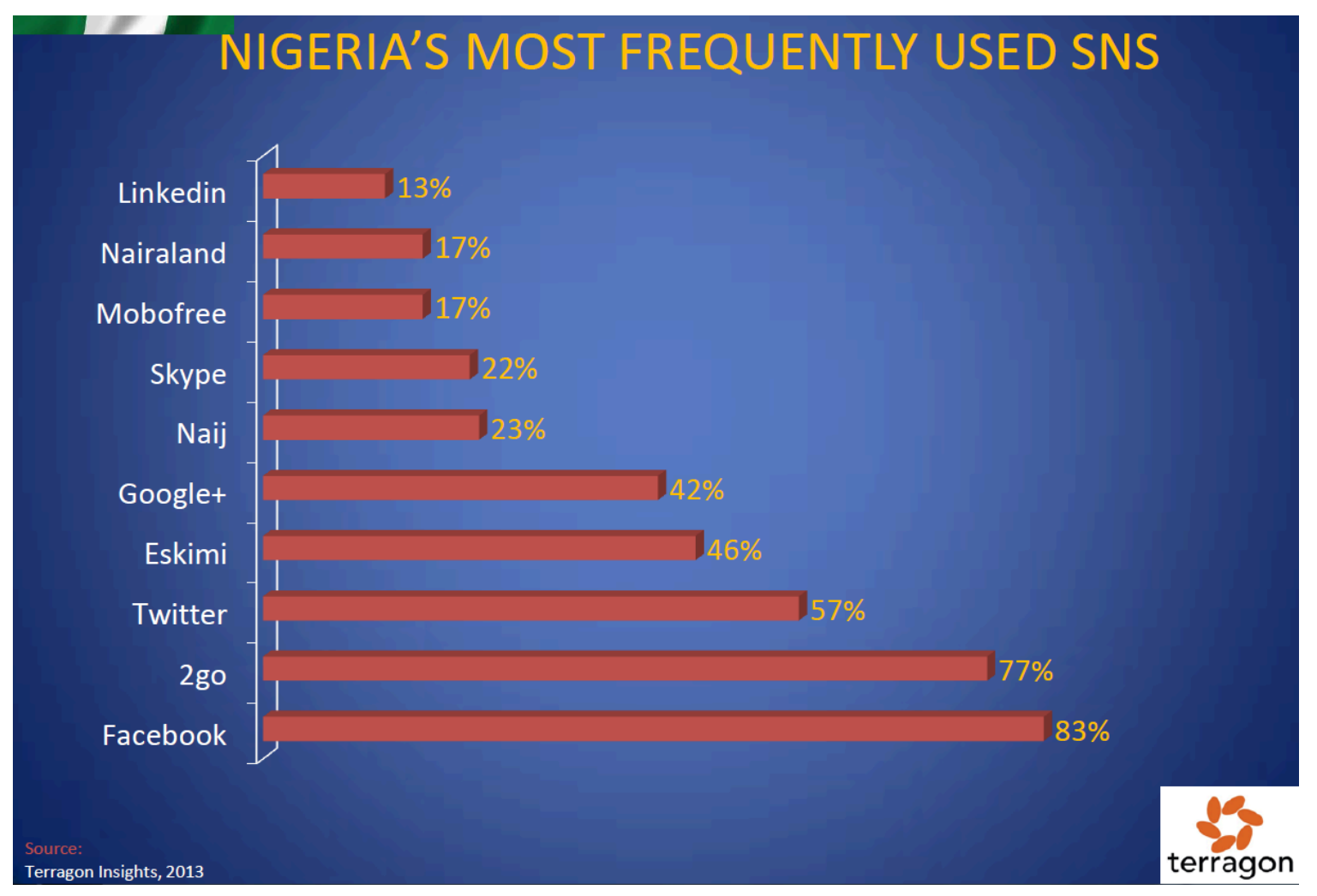

\section{Challenges and Limiting Factors}

Despite the very optimistic projections and successes recorded; particularly in utilizing the digital platforms to identify and reach; communicate and recruit; collaborate and retain global users; ultimately to achieve marketing objectives; including revenues boost, there exist factors that limit the full optimization of the e-marketing activities in the Nigerian entertainment and media (E\&M) industry. Even though the e-marketing activities unsettle and disrupt the traditional platforms; including causing a decline in their advertising dollars, evidence abounds to show that the Nigerian entertainment and media industry also relies on the traditional or other non-channels like newspapers, magazines, billboards, radios to reach their targets; ultimately suggesting efforts to complement the lapses that these digital platforms experience. For instance, the Nigerian Newspaper sector was noted to have a stable outlook; with small rises in revenue expected in 2021 and total industry revenue to hit US\$127 million (PwC's Global entertainment and media outlook 2017-2021). Moreover, when compared with the digital marketing platforms, traditional channels are non-interactive, non-flexible, non-dynamic and non-collaborative. The question becomes; why are competitors in the Nigerian E\&M industry also using traditional platforms in their marketing efforts if not to make-up for the lapses that the digital platforms limitations offer? These lapses largely limit the inherent opportunities and potentials that e-marketing presents for the industry especially one of an emerging country like Nigeria which should serve as a new market for driving economic growth.

Studies by Japhet \& Usman (2010) on barriers to e-commerce in developing countries 
identified factors such as the absence of adequate basic infrastructure, socio-economic and the lack of national government ICT strategies as limiting the full optimization of digital marketing. Ewah \& Ekeng (2009) noted low education, inadequate infrastructure, low patronage and civil unrest as responsible factors for limited e-marketing optimization. For studies conducted by Lawal \& Ogbu (2015), issues such as security, privacy, probability and content were identified as largely militating against e-marketing activities in Nigeria. These studies seem to have identified the limitations from a general perspective of what hinder the full optimization of e-marketing activities in Nigeria as a developing economy.

However, critical studies and analysis of the activities of digital marketing in the nation's entertainment and media (E\&M) industry show that some of these aforementioned factors had combined to distinctively undermine the definitive progression of the industry. These factors include; poor technology and infrastructural amenities; inadequate skills and human capital resulting in a shortage of platforms for exploitation of content and inadequate project development and business planning; copyright infringements and privacy issues. The combined activities of these factors largely limit the opportunities and potentials that e-marketing presents for the industry.

The first factor is poor technology and infrastructural amenities in the Country. Digital marketing platforms are generally internet-enabled which need continuous updating, upgrading and servicing to optimize performances and reliability. As a common feature in developing economies, there is limited access to technology. For Nigeria, even though the deregulation of the telecommunication sector brought about immediate and deep penetration of internet, there has been a deficiency in maintenance and upgrade of these facilities to support and ensure internet reliability and services. This has largely limited the wider spread of internet. Besides, the available internet and technologies are mostly seen and experienced in urban areas; which limits the participation of rural users in the e-marketing activities. The infrastructural facilities like transmission broadband, power supply, education, viable ICT reforms and government policy that supports internet boost are either in dilapidated form or entirely lacking. These have limited the bandwidth, connectivity and gateway to internet capable of handling audio and graphic data of the digital marketing content of the entertainment and media (E\&M) industry. There are unreliable electricity (power) supplies which Nigeria still battles with; which makes internet inaccessible and the digital marketing contents even when put out to the users, are also unable to be accessed and assessed (Humphrey, Mansell, Paré, \& Schmitz, 2003). These infrastructural deficiencies have combined to create problems of access to the digital marketing platforms; including access to conveniently create, critique, channel and commission entertainment content. Moreover, these factors have limited the adaption of technological hardware and software that would support E\&M companies to strengthen their capabilities in data analytics, measurement and management that are essential to build deeper users' insights and better targeting capabilities. Consequently, this presents a significant limitation to the optimization of e-marketing activities in the Nigerian media and entertainment (E\&M) industry.

Secondly, there is a challenge of inadequate skills and human capital. The lack of trained digital capacities and human capital in the Nigerian media and entertainment (E\&M) industry 
among its players; particularly the new entrants constitute a militating factor to the optimization of the e-marketing activities in the industry. This has led to the shortage or shortchanging of platforms for the exploration of content as well as inability to adequately plan and develop entertainment projects and media business. For instance, the lack of knowledge or ill-preparedness of an upcoming artist in digital approaches to marketing or adapting creative approaches to communicate content has the tendency to greatly undermine the prospects of a film or music production and how it gains acceptability among users' and fan base. The hands-on skills and knowledge of appropriate digital marketing platforms and how to combine the marketing mix is needed to achieve a robust e-marketing objective or outcome. Moreover, the industry could lose millions of dollars to poor skills in project development and business planning. In the case of mobile media platform, there have not been thorough business strategies and designs on how mobile access to content can trigger users' action. Critical to this poor hands-on-skills, is the inability of these E\&M players to effectively measure users' engagement, not just on mobile and digital marketing platforms, but across all service touchpoints. This is because one cannot improve on what was unable to be effectively measured. The optimization of e-marketing activities in the Nigerian entertainment and media (E\&M) industry remain restrained by the inability of its players to appreciate how and when a user is accessing specific E\&M content; consequently losing the potential for monetization through e-marketing. The growth of mobile internet access via smartphone ownership, and of mobile media consumption are unable to be wholly accounted for; to reflect the revenue generated by mobile marketing or users spend on mobile-only content. This is arguably because the core offering of mobile media could be said to be specifically not about the format of the device or the content consumed, but the fact that mobile consumption of marketing content is personal. A smartphone user in a city accesses content they want at a time and a place of their choice. The challenge for E\&M companies is that they must be more creative and develop adequate project and business plans to make their film, video game, music and news; the most appealing, convenient and gratifying for users who are faced with more leisure-time choices than ever before. Therefore, triggering users' action is essential to the success of e-marketing activities in E\&M and it entails adequate technical and business skills as well as cultivated human capital to achieve this.

Finally, there is a copyright infringements and privacy issues. The new media technologies empower users in terms of the capacity they present for engagement, interactions, creation of content and reach. Globally, these technologies are rapidly changing the world landscape; creating platforms that disrupt the traditional ways business are conducted, governance is being administered, communication is conducted and how people live their daily lives and transact with one another. For the digital marketing platforms, the new technologies enable markets and users across content, product, technology, distribution and sales to meet smoothly. However, the new technologies and these digital marketing platforms have created attendant problems including copyright infringements and privacy issues. These have also been identified as barriers to the full optimization of e-marketing activities in the Nigerian E\&M industry. Despite having a vibrant film and music industry, Nigeria has continued to strongly with copyright and piracy issues. The new media technologies and digital marketing platforms provide the room for users to access and duplicate creative content; either for a fee 


\section{Macrothink}

Case Studies in Business and Management

ISSN 2333-3324

2018, Vol. 5, No. 1

or free and giving opportunity for loss of morale and revenue among the industry players. According to the PwC's Global entertainment and media outlook 2017-2021, industries such as the world-renowned Nollywood, for instance, do not generate that much measurable revenue for the Nigerian E\&M due to issues such as piracy hampering official cinema owners and film vendors. Moreover, the twin factors of copyright infringements and privacy have generated an internet security issue as well as trust-issue in the e-marketing activities journey; in terms of making an online payment. Transactional trust is vital in the E\&M business but largely limited to user anxiety that conducting any form of payment or monetary transaction online would lead to a credit card fraud and identify theft. The potential users are suspicious of being cheated (Efendioglu et al., 2004). Even in the case of cyber fraud, the user bears the loss, usually without the financial institution's support; ultimately making the user reluctant to provide information and to use credit cards online. The lack of feel-and-touch associated with online purchases leave the user vulnerable and may induce feelings that privacy and security are not guaranteed in the current environment. In some cases, credit cards are not accepted for online transactions as part of security measures by the financial institutions. Beyond reaching, communicating, engaging and recruiting users, the full optimization and realization of e-marketing objectives depend on user transactions; including rapid payments and settlement of accounts.

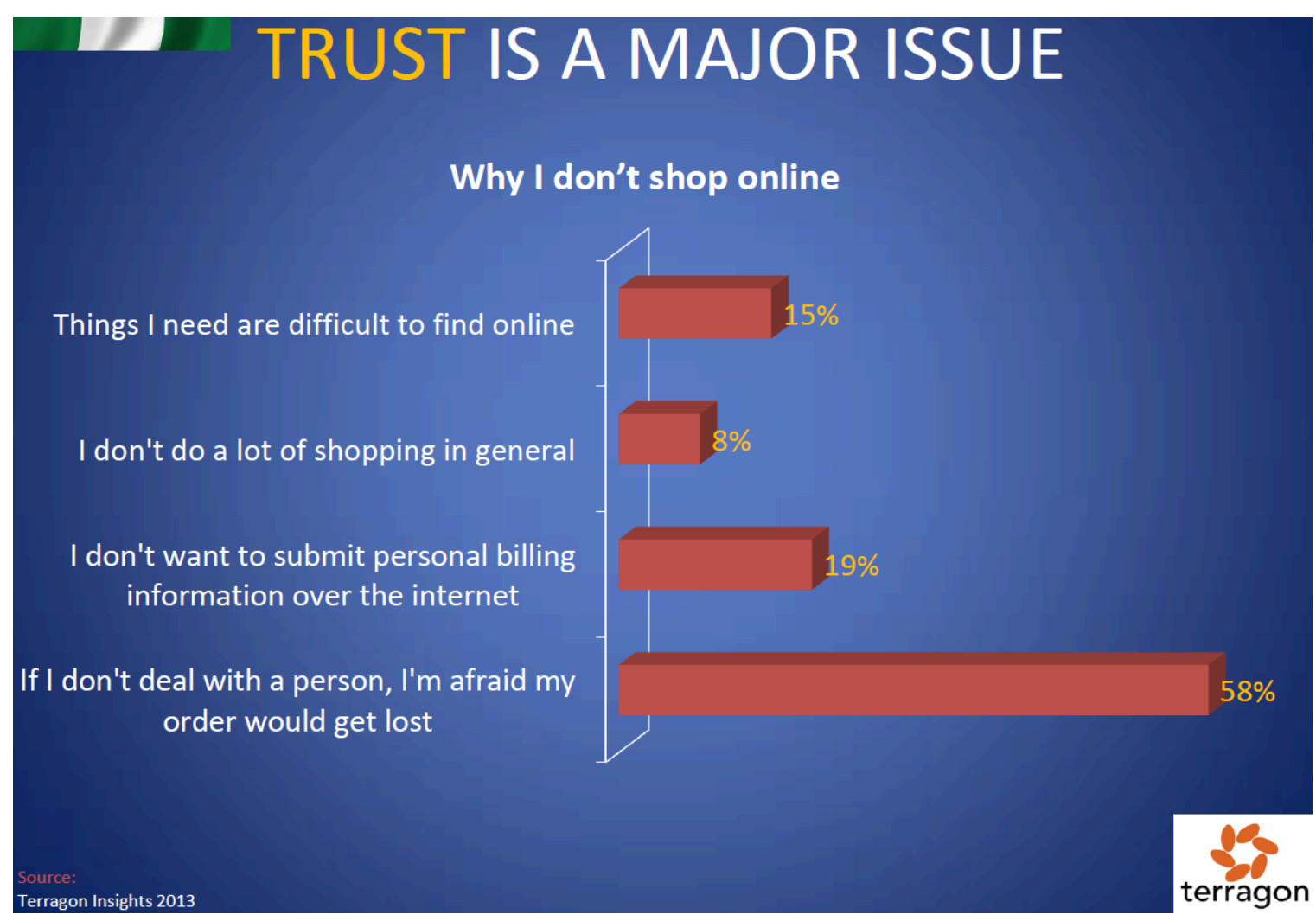

\section{Conclusion and Way Forward}

E-marketing activities in the Nigerian E\&M industry present opportunities and potential for 
profound valuable content development, communication facilitation, users' engagement and economic growth. The digital platforms and new media technologies have enormous potential as tools for the industry's development. However, these internet-enabled platforms and technologies have not been fully adapted and optimized to deliver enhanced services to key industry players and users or provide the necessary vehicle to drive a robust economy. The extent of adapting and optimizing these e-marketing platforms in the Nigerian E\&M industry are greatly limited by the combined efforts of several factors; including technological and infrastructural deficiencies; poor business and hands-on technological skills as well as security and privacy issues. Consequently, there is need for critical appraisal and viable actions to be taken to resolve these militating factors against the optimization of the e-marketing activities in the Nigerian entertainment \& media industry. The Nigerian Government, E\&M companies and users have a role and combined efforts to make in the actualization of an optimized E\&M industry. The Government must demonstrate the political will to remove the current barriers; including fixing the infrastructural facilities, such as transmission broadband and power supply, as well as embarking on viable ICT reforms and policies to support internet boost in the country. The government policies must be reviewed and strengthened to discourage and sanction copyright infringements, privacy issues and online transactional security concerns. More proactive measures must be put in place to make cyber transaction safe, to inspire confidence among industry players and users. Incentives, reforms and policies that advance the greatest possible use of market forces and competition to coordinate e-marketing in the industry must also be promoted. The E\&M companies and players must continue to train and retrain their manpower or personnel in emerging business and technological innovation; particularly in how they could support development of creative content, user-fan bases, monetize data and block revenue leakages in the industry. In line with fast-evolving, tech and experience-driven markets, Nigerian E\&M players must see the need to transform business structure, management model and culture; including laying emphasis on quality content and hands-on skills as well as supporting efforts that dissuade fraud, piracy and copyright issues in the industry. This would enhance the level of education, business and IT skills available for the entertainment and media (E\&M) businesses as well as build capacities for deeper user insight and targeting. The users must appreciate originality and respect creativity of work through patronizing only the original entertainment and media (E\&M) sources. This would include shunning copyright infringements and playing by the industry's rules of engagement. 


\section{References}

Adetayo, J. O., Sanni, S. A., \& Ilori, M. O. (1999). The impact of information technology on product marketing: A case study of a multinational company in Nigeria. Journal of Marketing, 19(11), 691-699. https://doi.org/10.1016/S0166-4972(99)00051-6

Adetutu, A., \& Eze, C. (2008). E-marketing in Nigeria: A survey of selected SMEs in Lagos. Journal of Business Communication, 4(3), 21-32.

Adomi, E. E. (2005). Internet development and connectivity in Nigeria. Program, 39(3), 257-268. https://doi.org/10.1108/00330330510610591

Akam, D. (2014). ICTs in product advertising in the Nigerian manufacturing sector: A survey of selected firms in Lagos and Port Harcourt. Nigeria Journal of Social Science, 9(2), 91-119.

Akasike, N. (2008). A study of Facebook as an advertising platform among small and medium scale enterprises in Nigeria. Journal of Management, 5(2), 341-356.

Aker, J. C. (2008). Does digital divide or provide? The impact of cell phones on grain markets in Nigeria (October 1, 2008). Center for Global Development Working Paper No. 154. Retrieved from http://ssrn.com/abstract=1093374

Amaefule, E. (2012). Nigeria joins top 20 Internet nations. The Punch, May 11, 2012. Retrieved from http://thepunchonline.com/news/Nigeria_joins/

Baran, J. S., \& Davis, D. K. (2001). Mass communication theory: foundations, ferment and future (3rd ed.). Belmont, CA: Thomson Wadsworth.

Durojaiye, A. O. (2003). Nigeria and struggle for economic emancipation. Sceptre Prints, Ibadan.

Efendioglu, A. M., Yip, V. F., \& Murray, W. L. (2004). E-Co g countries: issues and influences. San Francisco: University of San Francisco Press.

Ewah, S. O., \& Ekeng, A. B. (2009). Problems and Prospects of Marketing in Developing Economies: The Nigerian Experience. International Journal of Business and Management, 4(9). https://doi.org/10.5539/ijbm.v4n9p187

Failte Ireland. (2012). Overview of Internet Marketing. Retrieved from http://www.failteireland.ie/FailteIreland/media/WebsiteStructure/Documents/2_Develop_Yo ur_Business/3_Marketing_Toolkit/3_Market_Your_Business_Online/Choose\%20Your\%20In ternet\%20Tools/HowToGuide_IntMrktingOverview_v1-0.pdf

Federal Ministry of Finance, Report of empowerment programes of the federal government (2011-2012), Federal Government Press, Lagos.

GSMA Intelligence (2015). The Mobile Economy Sub-Saharan Africa. Retrieved from https://www.gsmaintelligence.com/research/?file=721eb3d4b80a36451202d0473b3c4a63\&d ownload 


\section{Macrothink}

Case Studies in Business and Management

ISSN 2333-3324

2018, Vol. 5, No. 1

Hassan, N. A. (2011). Social media marketing in Nigeria: A study of mobile phone networks. Nigerian Journal of Business Studies, 6(3), 129-144.

Humphrey, J., Mansell, R., Paré, D., \& Schmitz, H. (2003). The Reality of E-commerce with Developing Countries. London: Media Studies, LSE.

Inyang, A., Odu, S. A., \& Eleme, O. B. (2012). Online advertising among telecom service providers in Nigeria: A study of MTN and Globacom. African Communication Journal, 5(3), $222-243$.

Japhet, E. L., \& Usman, A. T. (2010). Barriers to ecommerce in developing countries. Information, Society and Justice, 3(1), 23-35.

Jobber, D., \& Ellis-Chadwick, F. (2013). Principles and Practice of Marketing (7th ed.). Berkshire: McGraw-Hill Education.

Juwah, E. (2011). Telecommunications business in Nigeria: how far? Speech presented at the international communications lecture organized by the Nigeria Swedish Chamber of Commerce, Commerce House, Victoria Island, Lagos 8 April, 2011. Retrieved from http://ncc.gov.ng/archive/EVCSpeches/20110408_Nigeria-Swedish_EVCSpeeches.pdf

Lawal, A., \& Ogbu, C. (2015). E-Commerce, Problems and Prospect in Nigeria. International Journal of Scientific Engineering and Applied Science, 1(3).

Liston, E. (2014). Hello Nollywood: how Nigeria became Africa's biggest economy overnight. The Guardian, April 10, 2014. Retrieved from http://www.theguardian.com/world/2014/apr/10/nigeria-africa-biggest-economy-nollywood

Mathew, J., Ogedebe, P. M., \& Ogedebe, S. M. (2013). Influence of web advertising on consumer behaviour in Maiduguri metropolis, Nigeria. Asian Journal of Social Sciences \& Humanities, 2(2). Retrieved from www.ajssh.leena-luna.co.jp

Omenugha, N.O, (2015), Communicating contents among Nigerian Telecommunication Service Providers: How has face-to-face Media fared? International Journal of Arts \& Sciences, Vol.08 (08), 551-562.

Othman, J. B. (2010). The current e-marketing activities of SME. Case Fotomina Ltd (Dissertation). Retrieved from https://www.theseus.fi/bitstream/handle/10024/28207/Jelena_BenOthman.pdf?sequence=1\&i sAllowed $=y$

Parsons, A., Zeisser, M., \& Waitman, R. (2015). ORGANIZING today for the Digital Marketing of Tomorrow. Journal of Interactive Marketing, 12(1), 31-36. https://doi.org/10.1002/(SICI)1520-6653(199824)12:1<31::AID-DIR4>3.0.CO;2-X

Peters, C. (2015). Appraising the effectiveness of Internet advertising among film marketers in Nigeria. African Communication Journal, 6(1), 322-339. 


\section{Macrothink \\ Case Studies in Business and Management ISSN 2333-3324 2018, Vol. 5, No. 1}

PwC Global. (2017). Global entertainment and media outlook 2017-2021. London. Retrieved from

https://www.pwc.com/ng/en/press-room/nigeria-will-be-the-worlds-fastest-growing-e-m-ma rket-pwc-report.html

Sassen, S. (2002). Towards a sociology of information. Current Sociology, 50(3), 365-388. https://doi.org/10.1177/0011392102050003005

Terragon Limited. (2013). State of Digital Media in Nigeria. Retrieved from https://nairametrics.com/wp-content/uploads/2013/05/Nigeria-State-of-Digital-Media.pdf

Uche, L. U. (2010). Digital culture in Nigeria: Perspectives and theories. African Journal of Communication, 3(6).

Wymbs, C. (2015). Social Media and Marketing Education: A Review of Current Practices in Curriculum Development. Journal of Marketing Education, 2, 76-87.

\section{Copyrights}

Copyright for this article is retained by the author(s), with first publication rights granted to the journal.

This is an open-access article distributed under the terms and conditions of the Creative Commons Attribution license (http://creativecommons.org/licenses/by/4.0/). 